Mongolian Academy of Sciences
Mongolian Journal of Chemistry
Institute of Chemistry \& Chemical Technology

\title{
The mechanochemical activation study of Tsagaan-tsav zeolite
}

\author{
Ts. Zolzaya, B. Davaabal, Z.Ochirbat, G. Oyun-Erdene, \\ A. Minjigmaa, J. Temuujin
}

Laboratory of Materials Science and Technology, Institute of Chemistry and Chemical Technology, Mongolian Academy of Sciences

\begin{abstract}
Characterisation of mechanochemically activated Tsagaan-tsav zeolite has been performed. Tsagaan-tsav zeolite has been activated with a vibration mill for 2, 3, 5, 10 and 20 minutes. Ball to powder ratios were varied 1:10, 1:20, 1:50 and 1:100. Efficiency of milling determined based on amorphisation rate and cation exchange capacity changes. The highest efficiency was obtained for zeolite milled with ball to powder ratio of 100. Structural characterisation was performed with XRD, SEM, BET and particle size analyzer. Mechanochemical activation improves cation exchange capacity of natural zeolite.
\end{abstract}

Keywords: natural zeolite, mechanical activation, amorphisation, cation exchange capacity

\section{Introduction}

$\mathrm{N}$ atural zeolite comprises an aluminosilicate framework with its channels filled with water and exchangeable cations [1] and are widely applied as catalysts in chemical industries like oil refining, basic petrochemistry, and fine chemistry [2]. Although there are more than thirty known natural zeolites, only seven - mordenite, clinoptilolite, ferrierite, chabazite, erionite, phillipsite and analcime - occur in sufficient quantity [3]. Mongolia is rich in natural zeolite reserves and the highest reserve zeolite is clinoptilolite from Tsagaan-tsav deposit [4]. The structure of zeolite is known to be composed of $(\mathrm{Si}, \mathrm{Al}) \mathrm{O}_{4}$ tetrahedra, which share all their oxygen vertices with neighboring tetrahedra. The negative charge of the framework is balanced by alkalis and alkaline earths located outside the tetrahedra, in the channels. Such alkaline and alkaline earths ions are called exchangeable cations [3]. Zeolite structure can be modified by either an acid or a base leaching to create mesopores and hence, to increase the surface area. At the same time some researchers suggested that mechanochemical activation of zeolite ruptures Al-O-Si bonding in zeolite thus improve the reactivity of the zeolite [5]. We have suggested that improving of the zeolite reactivity could cause improving of cation exchange capacity of a mechanically activated zeolite and may have some more applications. In this research, we have performed comparative study of zeolite after milling for a different duration.

\section{Experimental}

Natural zeolite samples from "Tsagaan-tsav" deposit in Saikhan-dulaan sum in Dondgovi-aimag was used as starting material. Chemical composition of zeolite was determined by XRF (Rigaku, Primini). Chemical composition of zeolite was (wt\%): $\mathrm{SiO}_{2}$ (72.6), $\mathrm{Al}_{2} \mathrm{O}_{3}$ (14.8), $\mathrm{K}_{2} \mathrm{O}$ (4.2), $\mathrm{Na}_{2} \mathrm{O}$ (3.54), $\quad \mathrm{Fe}_{2} \mathrm{O}_{3}$ (2.16), $\mathrm{CaO}$ (1.51), $\mathrm{MgO}$ (0.709), $\mathrm{TiO}_{2}(0.207), \quad \mathrm{SrO}(0.125), \mathrm{P}_{2} \mathrm{O}_{5}$ (0.0417). 
The Mechanochemical activation was performed with the vibration mill BMC. Steel balls were used as milling medium and ratio of ball to powder varied as 10:1, 20:1, 50:1 and 100:1. Samples were milled for 2, 3, 5, 10 and 20 minutes. Before and after milling, zeolite samples were characterised by particle size analyzer (Shimadzu, SALD-2100), BET (Bellsorp mini) and XRD (Brucker D8Advance). Cation exchange capacity was determined by a classical method. Preliminary study of the raw and milled zeolites showed the ball to powder ratio 100:1 is giving the best cation exchange capacity. Therefore, further experiments carried out based on the samples milled with ball to powder ratio of 100:1.

\section{Results and Discussion}

Fig. 1 shows XRD patterns of the raw and milled zeolite samples. Tsagaan tsav zeolite consists of minerals such as clinoptilolite, heulandite and dickite. Apparently, presence of the strontium in raw zeolite was caused with presence of the heulandite which contains strontium in its chemical makeup very often. The main mineral phases are clinoptilolite and heulandite while dickite belongs to kaolinite group. Table 1 shows identified mineral phases in raw zeolite. Longer milling destroys crystalline structure of the original minerals and 20 min milling caused almost full amorphisation of the Tsagaan tsav zeolite.

Amorphisation rate of the milled samples was determined by the following equation:

$A=100-K, \% ; K=\left(\frac{I_{a c}}{I_{\text {raw }}}\right) \cdot 100, \%$

A-amorphisation $\%, \mathrm{~K}$ - crystallinity $\%, \mathrm{I}_{\mathrm{ac}}-\mathrm{X}$ ray diffraction intensity of activated sample, $\mathrm{I}_{\text {raw }} \mathrm{X}$ ray diffraction intensity of raw sample

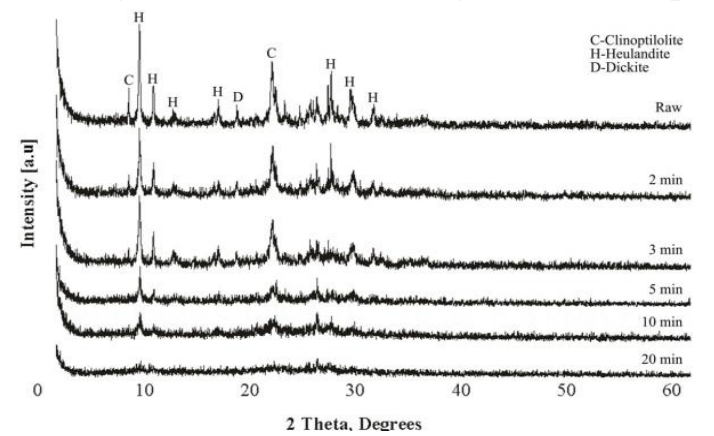

Fig.1 XRD patterns of the raw and activated Tsagaan tsav zeolite.
Table 1. Mineral phase identification of raw zeolite

\begin{tabular}{|c|c|c|c|c|}
\hline № & hkl & 2-theta & \begin{tabular}{|l|} 
Spacing \\
$\mathrm{d}, \mathrm{A}^{\circ}$
\end{tabular} & Minerals \\
\hline 1 & $(020)$ & 9.91 & 9.78 & $\begin{array}{l}\text { Clinoptilolite, }(\mathrm{Na}, \mathrm{K}, \mathrm{Ca})_{2-} \\
{ }_{3} \mathrm{Al}_{3}(\mathrm{Al}, \mathrm{Si})_{2} \mathrm{Si}_{13} \mathrm{O}_{36} \cdot 12\left(\mathrm{H}_{2} \mathrm{O}\right)\end{array}$ \\
\hline 2 & $(200)$ & 11.12 & 8.83 & Heulandite, $(\mathrm{Ca}, \mathrm{Na})_{2-3} \mathrm{Al}_{3}\left(\mathrm{Al}, \mathrm{Si}_{2} \mathrm{Si}_{13} \mathrm{O}_{36} \cdot 12 \mathrm{H}_{2} \mathrm{O}\right.$ \\
\hline 3 & (111) & 17.28 & 7.87 & Heulandite, $(\mathrm{Ca}, \mathrm{Na})_{2-3} \mathrm{Al}_{3}\left(\mathrm{Al}, \mathrm{Si}_{2}\right)_{2} \mathrm{Si}_{13} \mathrm{O}_{36} \cdot 12 \mathrm{H}_{2} \mathrm{O}$ \\
\hline 4 & $(330)$ & 22.47 & 6.6 & Dickite, $\left(\mathrm{Al}_{2} \mathrm{Si}_{2} \mathrm{O}_{5}(\mathrm{OH})_{4}\right)$ \\
\hline 5 & $(31 \underline{2})$ & 24.90 & 5.0 & $\begin{array}{ll}\text { Clinoptilolite, } & (\mathrm{Na}, \mathrm{K}, \mathrm{Ca})_{2} \\
{ }_{3} \mathrm{Al}_{3}\left(\mathrm{Al}, \mathrm{Si}_{2} \mathrm{Si}_{13} \mathrm{O}_{36} \cdot 12\left(\mathrm{H}_{2} \mathrm{O}\right)\right.\end{array}$ \\
\hline 6 & $(002)$ & 26.70 & 4.68 & Heulandite, $(\mathrm{Ca}, \mathrm{Na})_{2-3} \mathrm{Al}_{3}\left(\mathrm{Al}, \mathrm{Si}_{2}\right)_{2} \mathrm{Si}_{13} \mathrm{O}_{36} \cdot 12 \mathrm{H}_{2} \mathrm{O}$ \\
\hline 7 & $(351)$ & 29.80 & 3.85 & Heulandite, $(\mathrm{Ca}, \mathrm{Na})_{2-3} \mathrm{Al}_{3}\left(\mathrm{Al}, \mathrm{Si}_{2} \mathrm{Si}_{13} \mathrm{O}_{36} \cdot 12 \mathrm{H}_{2} \mathrm{O}\right.$ \\
\hline 8 & $(260)$ & 32.14 & 3.11 & Heulandite, $(\mathrm{Ca}, \mathrm{Na})_{2-3} \mathrm{Al}_{3}\left(\mathrm{Al}, \mathrm{Si}_{2} \mathrm{Si}_{13} \mathrm{O}_{36} \cdot 12 \mathrm{H}_{2} \mathrm{O}\right.$ \\
\hline
\end{tabular}

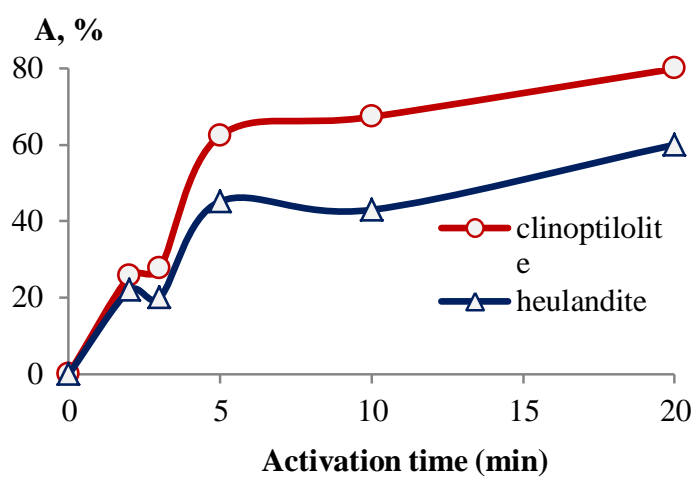

Fig.2. Influence of activation time in amorphisation of the zeolite samples.

Fig. 2 shows also clinoptilolite mineral is amorphising more easily than heulandite mineral, though their mineral structures are closely related.

Mechanical activation of solid particle decreases its particle size and increases specific surface area. Specific surface area change of the zeolite samples with milling times is shown in Fig.3.

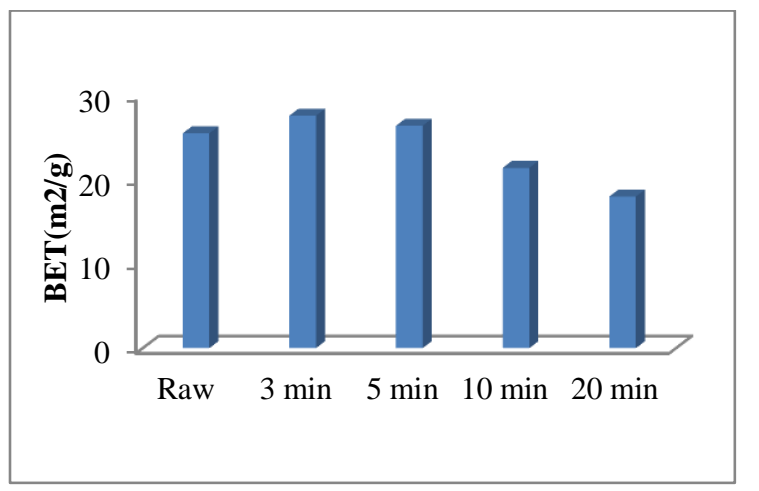

Fig.3. Change of the specific surface area of zeolite samples with milling times.

Fig. 3 indicates that short milling time caused increasing of the surface area possibly by reduction of the particle size. However, after 5 min milling the surface area begin to decrease. After 20 min milling the surface area decreased more than $20 \%$ of the original 
value. The decrease of the surface area is one of the indications of particle agglomeration behaviour as it is usually observed for clay minerals [6]. It can be suggested that there is the practical limit to grinding for particle size reducing at which the particles of natural zeolite re-aggregate.

Particle size distribution of the raw and milled zeolite is shown in Table 2. The values presented in Table 2 are well agreement with the Fig.3.

Table 3. Particle size distribution of raw and activated zeolite

\begin{tabular}{|c|c|c|c|c|c|}
\hline № & Sample & $\begin{array}{c}25 \% \\
(\mu \mathrm{m})\end{array}$ & $\begin{array}{c}50 \% \\
(\mu \mathrm{m})\end{array}$ & $\begin{array}{c}75 \% \\
(\mu \mathrm{m})\end{array}$ & $\begin{array}{c}99 \% \\
(\mu \mathrm{m})\end{array}$ \\
\hline 1 & Raw zeolite & 74.203 & 153.279 & 241.981 & 531.963 \\
\hline 2 & $\begin{array}{c}2 \text { min } \\
\text { activated } \\
\text { zeolite }\end{array}$ & 18.484 & 72.054 & 161.440 & 440.126 \\
\hline 3 & $\begin{array}{c}3 \text { min } \\
\text { activated } \\
\text { zeolite }\end{array}$ & 22.980 & 75.542 & 160.453 & 543.623 \\
\hline 5 & $\begin{array}{c}5 \text { min } \\
\text { activated } \\
\text { zeolite }\end{array}$ & 101.659 & 218.322 & 448.125 & 836.539 \\
\hline $\begin{array}{c}10 \text { min } \\
\text { activated } \\
\text { zeolite }\end{array}$ & 44.335 & 115.75 & 186.288 & 654.760 \\
\hline $\begin{array}{c}\text { 20 min } \\
\text { activated } \\
\text { zeolite }\end{array}$ & 76.312 & 176.021 & 312.271 & 804.570 \\
\hline
\end{tabular}

The median size (50\%) of the activated zeolite shows clear tendency to increase after just 2 min milling. In other words, particle agglomeration occurs just after very short milling time and it may be results of either a strong milling regime (ball to powder ratio of 100:1) or low hardness of natural zeolite.

Cation exchange capacity (CEC) change of the raw and milled zeolite is shown in Fig.4. Cation exchange capacity (CEC) increased from $2.56(\mathrm{mg}-\mathrm{eq} / 100 \mathrm{~g})$ to $3(\mathrm{mg}$ eq/100) after $20 \mathrm{~min}$ milling. There is steep increase in CEC after 2 min milling. CEC is expected to increase when there are more exchangeable cations. Previous result indicates that the zeolite agglomeration occurred with longer milling, but agglomerated zeolites were more amorphised. Probably, amorphisation of the zeolite is responsible for increased CEC. In this zeolite the exchangeable cations varied with $\mathrm{K}>\mathrm{Na}$ $>\mathrm{Ca}>\mathrm{Mg}$ sequence, where $\mathrm{K}$ presents mostly in clinoptilolite. Therefore, it can be suggested that amorphisation of the clinoptilolite is the main factor for improved CEC. It is likely that not entire exchangeable cations of the zeolite minerals are participating in cation exchange reaction. Possibly amorphisation of the zeolite raptures some Al-O-S bonds in zeolite thus reduces charge balancing requirement of the zeolite framework which was not participated in cation exchange reaction of the raw zeolite.

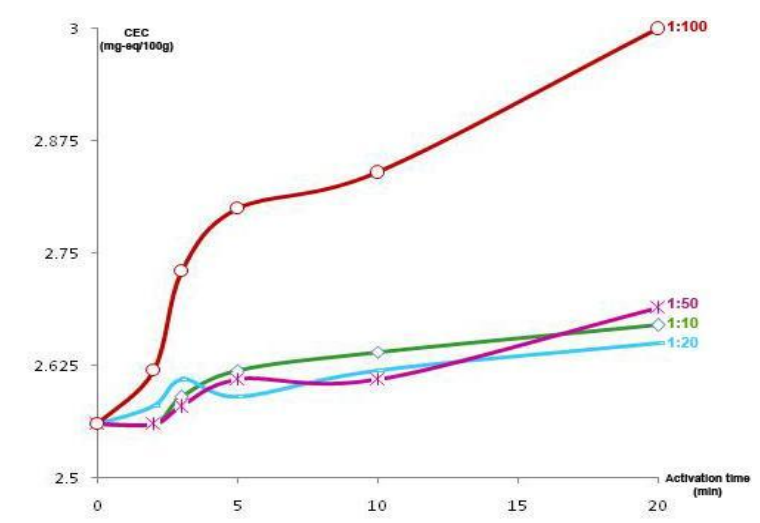

Fig.4. Cation exchange capacity of the raw and milled zeolite

\section{Conclusions}

Natural zeolite from Tsagaan tsav deposit was treated mechanically with ball to powder ratio of 100:1 by vibration mill for 2, 3, 5, 10 and 20 minutes. Mechanical activation reduces particle size of the raw zeolite, but reagglomeration takes place after 5 min milling. Cation exchange capacity of the milled zeolite increased from 2.56 to $3 \mathrm{mg}-\mathrm{eq} / 100 \mathrm{~g}$. Amorphisation of the milled zeolite accompanied by rapture of the $\mathrm{Si}-\mathrm{O}-\mathrm{Al}$ bonds is thought to be the main reason for the CEC increase.

\section{References}

1. Gottardi, G. Mineralogy and crystal chemistry of zeolites, in Natural zeolites, occurrence, properties, use, eds Sand, L.B., Mumpton, F.A. Pergamon, Oxford,(1978) pp.31-44

2. Van Donk, S., Janssen, A.H., Bitter, J.H., De Jong, K.P. Catalysis Reviews, Vol. 45, No. 2, pp. 297-319, 2000

3. Minjigmaa, A., Temuujin, J., Burmaa, G., Jadambaa, Ts., Enkhtuya, D., Senna, M., Bazarova, J., Improved reactivity of natural zeolite by acid activation and its application for water 
purification, Vestnik of Buryat State University, 2008, pp80-83

4. Temuujin, J., "Mineral resources and industrial wastes of Mongolia and their application for value added products" Bembi san publisher, Ulaanbaatar 2007

5. Shumskaya, L.G., Kirillova, Ye.A., Yusupov, T.S., Controlled changes in technological properties of phosphates in mechanical activation with zeolites, J.Mining Sci., 35, 1999, 96-100
6. Temuujin, J., Okada, K., Jadambaa, Ts., MacKenzie, K.J.D., Amarsanaa, J., Effect of grinding on the leaching behaviour of pyrophillite, J.Eur.Ceram.Soc., 23 (2003) 12771282 